Massimo Mangino $\cdot$ Isabella Torrente

Alessandro De Luca · Otto Sanchez • Bruno Dallapiccola

Giuseppe Novelli

\title{
A single-nucleotide polymorphism in the human bone morphogenetic protein-4 (BMP 4) gene
}

Received: July 21, 1998 / Accepted: August 25, 1998

\begin{abstract}
A polymorphic site has been found in the human bone morphogenetic protein-4 (BMP4) gene. To our knowledge, it is the first defined polymorphism in this gene, being present with similar frequencies in Caucasian, Hispanic, and African populations.
\end{abstract}

Key words BMP4 $\cdot$ Chromosome $14 \cdot$ Polymorphism Osteoporosis $\cdot$ Arthritis

\section{Introduction}

Bone morphogenetic protein (BMP4) is a member of the BMP family, which belongs to the transforming growth factor- $\beta$ (TGF- $\beta$ ) superfamily (Wozney et al. 1988). BMP4 can induce de nov cartilage and bone formation, and appears to be essential for skeletal development during mammalian embryogenesis (Reddi 1998). BMP4 is one of the best evolutionary conserved growth factors and is necessary to induce mesoderm formation (Winnier et al. 1995). The structure of the gene and the boundaries of the intronic sequences are known (van den Wijngaard et al. 1996). We report here the first known polymorphic site in this gene and its frequency in three ethnic groups.

Primers for the polymerase chain reaction (PCR)

The primers used for PCR were: BMP 4-F: 5'CCTAACTGTGCCTAG-3' and BMP 4-R: 5'CATAACCTCATAAATGTTTATACGG-3' .

Massimo Mangino $\cdot$ Isabella Torrente $\cdot$ Alessandro De Luca $\cdot$ Bruno Dallapiccola $\cdot$ Giuseppe Novelli $(\bowtie)$

Cattedra di Genetica Umana e Medica, Dipartimento di

Biopatologia e Diagnostica per Immagini, Università di Roma "Tor

Vergata" e CSS Istituto Mendel, Roma, Via di Tor Vergata 135-

00133 Roma, Italy

Tel. +39-06-7259-6080; Fax +39-06-2042-7313

e-mail: novelli@med.uniroma2.it

Otto Sanchez

Unidad de Genetica, Escuela de Medicina, Universidad de Oriente,

Ciudad Bolivar, Venezuela

\section{Polymorphism and allele frequency}

HphI polymorphism. HphI digestion produced a 197-bp fragment in the A147 allele that lacks the HphI site, while the digestion detected 110-bp and 87-bp fragments in the V147 allele having the recognition site (Fig. 1).

Allele frequencies. The estimated A147/V147 allele frequencies in 136 chromosomes from unrelated individuals from different ethnic groups are summarized in Table 1. The polymorphism information content (PIC) was 0.365 .

Chromosome localization. The human BMP4 gene has been assigned to chromosome 14q22-23 (Tabas et al. 1993; van den Wijngaard et al. 1995).

Mendelian inheritance. Mendelian inheritance was confirmed in four three-generation families.

\section{Other comments}

To detect the HphI restriction fragment length polymorphism, PCR was carried out in a total volume of $25 \mu$, containing $200 \mathrm{ng}$ of genomic DNA, $10 \mathrm{mM}$ Tris $\mathrm{HCl}(\mathrm{pH}$ 8.4), $50 \mathrm{mM} \mathrm{KCl}, 2.5 \mathrm{mM} \mathrm{MgCl} 2,0.01 \%$ of gelatin, $200 \mu \mathrm{M}$ dNTPs per, $25 \mathrm{pmol}$ of each primer, and 0.25 units of Taq polymerase. Cycle conditions were $94^{\circ} \mathrm{C}$ for $12 \mathrm{~min}$, then 30 cycles of $94^{\circ} \mathrm{C}$ for $1 \mathrm{~min}, 56^{\circ} \mathrm{C}$ for $1 \mathrm{~min}$, and $72^{\circ} \mathrm{C}$ for $1 \mathrm{~min}$, with a final extension step of $7 \mathrm{~min}$ in a gene Amp PCR9600 System (Perkin Elmer Cetus, Norwalk, CT, USA). The PCR products (197bp) were digested with HphI and subjected to electrophoresis on a $2 \%$ MS-8 (Hispanagar Burgos, Spain), agarose gel. The polymorphic HphI site was localized to nucleotide position $538(\mathrm{~T} \rightarrow \mathrm{C})$, resulting in an amino acid change of $\mathrm{Val} \rightarrow$ Ala (V147A) in the polypeptide. The polymorphism in the BMP4 gene may be of interest in the study of human bone and joint diseases (e.g., osteoporosis and arthritis). This single-nucleotide polymorphism (SNP) should also be useful in establishing an SNP genetic map (Wang et al. 1998). 


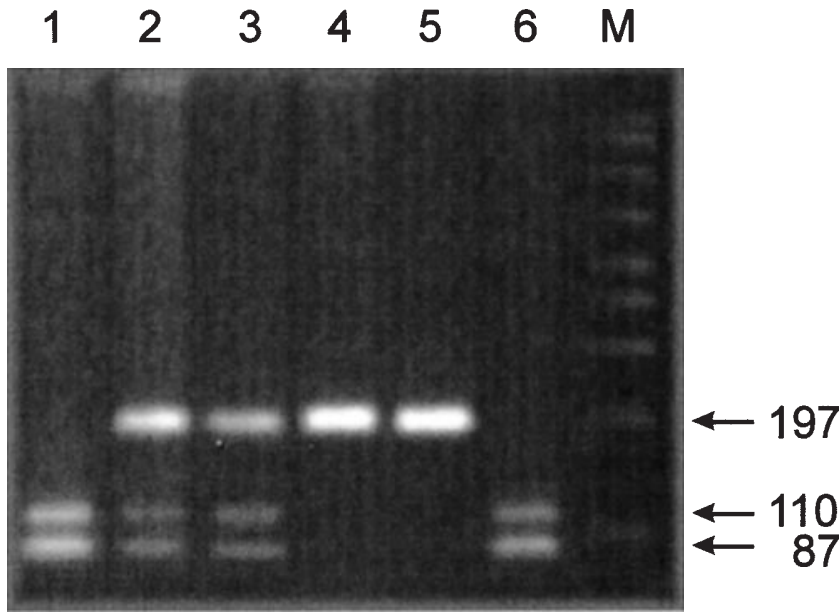

Fig. $1 \mathrm{HphI}$ restriction fragment polymorphism (RFLP). Lanes 1 and 6 are homozygous for $\mathrm{V} / \mathrm{V}$. Lanes 2 and 3 are heterozygous for $\mathrm{A} / \mathrm{V}$. Lanes 4 and 5 are homozygous for A/A. Lane $M$, AmpliSize Molecular Ruler (50-2000bp, Bio Rad, Richmond, CA, USA)

Table 1 Polymorphism at amino acid position 147 of the human bone morphogenetic protein (BMP4) gene, and gene frequencies in different ethnic groups

\begin{tabular}{|c|c|c|c|c|c|c|}
\hline \multirow[b]{2}{*}{ Ethnic group } & \multirow[b]{2}{*}{$n$} & \multicolumn{3}{|c|}{ Genotypes } & \multicolumn{2}{|c|}{$\begin{array}{l}\text { Gene } \\
\text { frequencies }\end{array}$} \\
\hline & & $\mathrm{V} / \mathrm{V}$ & $\mathrm{A} / \mathrm{V}$ & $\mathrm{A} / \mathrm{A}$ & $147 \mathrm{~V}$ & $147 \mathrm{~A}$ \\
\hline Caucasian & 30 & 10 & 16 & 4 & 0.6 & 0.4 \\
\hline Hispanic & 19 & 9 & 8 & 2 & 0.68 & 0.32 \\
\hline African & 19 & 8 & 9 & 2 & 0.65 & 0.35 \\
\hline
\end{tabular}

$\mathrm{V}=$ Valine, $\mathrm{A}=$ Alanine
Acknowledgments This work was supported by the Ministero della Sanità, Italy.

\section{References}

Reddi AH (1998) Role of morphogenetic proteins in skeletal tissue engineering and regeneration. Nat Biotechnol 16: 247-252

Tabas JA, Hahn GV, Cohen RB, Seaunez HN, Modi WS, Wozney JM, Zasloff M, Kaplan FS (1993) Chromosomal assignment of the human gene for bone morphogenetic protein 4. Clin Orthop Rel Res 293: $310-316$

Van den Wijngaard A, Olde Weghuis D, Boersma CJC, van Zoelen EJJ, Geurts van Kessel A, Olijve W (1995) Fine mapping of the human bone morphogenetic protein-4 gene (BMP4) to chromosome 14q22-q23 by in situ hybridization. Genomics 27: 559-560

Van den Wijngaard A, van Kraay M, van Zoelen EJJ, Olijve W, Boersma CJC (1996) Genomic organization of the human bone morphogenetic protein-4 gene: Molecular basis for multiple transcripts. Biochem Biophys Res Commun 219: 789-794

Wang DG, Fan JB, Siao CJ, Berno A, Young P, Sapolsky R, Ghandour G, Perkins N, Winchester E, Spencer J, Kruglyak L, Stein L, Hsie L, Topaloglou T, Hubbell E, Robinson E, Mittmann M, Morris MS, Shen N, Kilburn D, Rioux J, Nusbaum C, Rozen S, Hudson TJ, Lipshutz R, Chee M, Lander ES (1998) Large-scale identification, mapping and genotyping of single-nucleotide polymorphisms in the human genome. Science 280: 1077-1082

Winnier G, Blessing M, Labosky PA, Hogan BL (1995) Bone morphogenetic protein-4 is required for mesoderm formation and patterning in the mouse. Gene Dev 9: 2105-2116

Wozney JM, Rosen V, Celeste AJ, Mitsock LM, Whitters MJ, Kriz RW, Hewick RM, Wang EA (1988) Novel regulators of bone formation: Molecular clones and activities. Science 242: 1528-1534 